\title{
Application of waterworks sludge in wastewater treatment plants
}

\author{
A. K. Sharma $\cdot$ D. Thornberg $\cdot$ H. R. Andersen
}

Received: 19 June 2012/Revised: 26 October 2012/ Accepted: 1 January 2013/Published online: 28 February 2013

(C) Islamic Azad University (IAU) 2013

\begin{abstract}
The potential for reuse of iron-rich sludge from waterworks as a replacement for commercial iron salts in wastewater treatment was investigated using acidic and anaerobic dissolution. The acidic dissolution of waterworks sludge both in sulphuric acid and acidic products such as flue gas washing water and commercial iron solution was successful in dissolving the iron from waterworks sludge. The anaerobic dissolution of waterworks sludge due to codigestion with biological sludge (primary and biological activated sludge) resulted in reduction of iron, increase in dissolved iron(II), increase in $\mathrm{pH}$ due to the produced alkalinity from dissolution of iron(III)hydroxides from waterworks sludge, lower internal recirculation of phosphate concentration in the reject water and reduced sulphide in the digested liquid. However, recirculation of the produced soluble iron(II) as an iron source for removal of phosphate in the wastewater treatment was limited, because the dissolved iron in the digester liquid was limited by siderite $\left(\mathrm{FeCO}_{3}\right)$ precipitation. It is concluded that both acidic and anaerobic dissolution of iron-rich waterworks
\end{abstract}

A. K. Sharma · H. R. Andersen

Department of Environmental Engineering, Technical University of Denmark (DTU), Miljoevej, Building 113,

2800 Kgs. Lyngby, Denmark

\section{Thornberg}

Avedøre Wastewater Services, Kanalholmen 28,

2680 Hvidovre, Denmark

H. R. Andersen ( $\square)$

Department of Environmental Engineering, Technical University of Denmark, Bygningstorvet, Building 115,

2800 Kgs. Lyngby, Denmark

e-mail: henrik@ndersen.net

URL: www.env.dtu.dk sludge can be achieved at the wastewater treatment plant, and are economically and environmentally more favourable compared to deposition of the waterworks sludge in controlled landfills.

Keywords Water works - Sludge - Wastewater - Iron · Phosphate

\section{Introduction}

Iron and aluminium salts are widely used for chemical precipitation at wastewater treatment plants (WWTP) for enhancing removal of a number of substances like phosphate, total suspended solids (TSS) and chemical oxygen demand (COD). Furthermore, iron salts are also used for control of hydrogen sulphide $\left(\mathrm{H}_{2} \mathrm{~S}\right)$ in biogas and stabilization of sludge for application on land. Usage of commercial iron and aluminium salts contributes substantially to the total operational cost at a WWTP. As an example, the usage of iron for removal of phosphate at Avedøre WWTP in Denmark accounts for approximately $10 \%$ of the total running costs (electricity, polymer, and chemicals) for the wastewater treatment (Sharma et al. 2011).

Since the iron and aluminium salts used in WWTPs do not need to be chemically pure, various waste materials or by-products rich in iron and aluminium can be substituted for pure chemicals and thereby reduce the treatment cost and resource use. Waterworks sludge (WWS) (e.g. Babatunde and Zhao 2007; Ippolito et al. 2011; Ishikawa et al. 2007), fly ash (Yan et al. 2007), red mud (e.g. citation in Liu et al. 2011), blast furnace slag (e.g. Lu et al. 2007), mine tailings (e.g. Zeng et al. 2004) are some of the metalrich waste products studied in the literature for their applicability in WWTP and for phosphate removal. 
The application of WWS has a great potential, since WWS is available all over the world as a by-product produced at waterworks (WW) during the coagulation process, which is the most common process applied in drinking water treatment. Even in countries like Denmark with no need for addition of coagulants in the drinking water production, due to relatively pure groundwater as a water source, iron-rich WWS is produced in substantial quantities due to the naturally occurring iron in the groundwater (Bækgaard 1997).

According to (Aktor 1990), there is no difference between the iron(hydr)oxides formed from naturally occurring iron in the raw water and iron(hydr)oxides formed from iron added as coagulant.

Dharmappa et al. (1997) estimated that the global daily production of WWS was 10,000 tons/day. WWS production has been increasing over years because of increased production of drinking water and stringent drinking water regulations. Basibuyuk and Kalat (2004) predicted that the WWS production in Europe will double over the next decade.

A survey by the Danish Water and Wastewater Association (DANVA) showed that depending on the possibilities and characteristics of WWS, the options for handling WWS in Denmark were deposition (on land near the waterworks or on official landfills), reuse in biogas production plants to control sulphide, discharge to WWTPs (either dump into aeration tanks or discharging the filter backwash water into the sewer system), and application on agricultural land as a fertilizer (it is uncertain if the sludge has any value as a soil improvement remedy) (DANVA 2009). Depositing the sludge in protected landfills is costly, and further a tax of $70 € /$ ton WWS (wet weight) is about to be implemented in Denmark which will make sludge disposal costly for WWs. Furthermore, the increased awareness on the trace concentrations of other metals of environmental concern of WWS questions the soundness of past practices like depositing WWS on unprotected grounds or spreading it on agricultural land. Discharging WWS onto unprotected landfills is about to be restricted in Denmark due to increasing stringent regulations for metals of environmental concern (e.g. DANVA 2009). This will drive WWs to find alternative affordable ways of discharging the WWS and this can increase the profitability of usage of WWS at WWTP.

The literature review by Babatunde and Zhao (2007) shows that WWS has been tested for various applications like dewatering of sludge, removal of phosphate, COD and TSS at WWTPs. As far back as 1903, a patent was obtained on the recycling of WWS for removal of various pollutants in wastewater (cited in Babatunde and Zhao 2007). Increasing interest in the usage of WWS for the removal of phosphate at the WWTP is seen in the past two decades in the form of many laboratory studies (e.g. Babatunde and Zhao 2010; Ippolito et al. 2003; Yang et al. 2009; Zhao et al. 2007); however, the reuse of WWS at WWTP is rarely seen in practice. The reported studies on phosphate removals with WWS show that the sorption of phosphate is a two-stage process: a quick sorption followed by slow sorption (cited in Ippolito et al. 2011). The review by Ippolito et al. (2011) further shows that the sorption capacity of WWS varies between 1.74 and $37 \mathrm{mg}-\mathrm{P} / \mathrm{g}$ WWS and depends on factors like particle size, co-occurring ions, shaking time and solution $\mathrm{pH}$.

Alum is the most commonly used coagulant at WWs, especially in the United States and Canada. Hence the majority of studies on WWS reuse have been performed with aluminium-rich WWS (e.g. Babatunde and Zhao 2010; Ippolito et al. 2003; Makris et al. 2004; Yang et al. 2009; Zhao et al. 2007) and very few were based on ironrich WWS (e.g. Makris et al. 2004; Leader et al. 2008). Makris et al. (2004) reported lower sorption capacity of iron-rich WWS ( $2 \mathrm{mg}-\mathrm{P} / \mathrm{g}-\mathrm{WWS}$ ) compared to aluminiumrich WWS (7.7 mg-P/g-WWS).

Iron-rich sludge from treatment of acidic mine wastewater (MWS), which has similar or higher iron content compared to iron-rich WWS, has also been tested for its sorption capacity for phosphate from biologically treated wastewater (Dobbie et al. 2009; Heal et al. 2003, 2005; Sibrell et al. 2009; Wei et al. 2008) with maximum sorption capacity of $30 \mathrm{mg}-\mathrm{P} / \mathrm{g}-\mathrm{MWS}-\mathrm{dw}$ (Heal et al. 2003; Wei et al. 2008). This is comparable to the values reported by Ippolito et al. (2011) in a recent review on WWS uses, and 30 to $>200$-fold better than other minerals and waste products like slags and ashes of different origin (Heal et al. 2003).

These studies show that WWS can be applied for removal of phosphate; however, it is well known that the removal of phosphate is higher upon addition of aluminium and iron as soluble salts leading to co-precipitation and adsorption on simultaneously formed aluminium and iron hydroxides compared to the sorption on preformed aluminium and iron hydroxides as found in WWS. For example, Smith et al. (2008) reported that the phosphate removal capacity in poorly mixed systems with phosphate exposed to preformed ironhydroxides decreased to $25 \%$ of the well-mixed systems, where phosphate and iron were added simultaneously. Furthermore, Dixit and Hering (2003) reported that the arsenate sorption capacity (phosphate and arsenate have similar adsorption mechanisms (Sharma 2003)) of Goethite is $>10$ times lower than the sorption capacity of amorphous iron hydroxides.

Therefore, it is expected that phosphate removal capacity of WWS can be increased significantly by dissolving WWS before using for the wastewater treatment process. It is well known that iron and aluminium hydroxides from WWS can be dissolved at very low 
$(\mathrm{pH}<2)$ as well as very high $\mathrm{pH}(\mathrm{pH}>11$ for $\mathrm{Al}$ and $\mathrm{pH}$ $>13$ for iron). Iron hydroxides can also be dissolved under reducing conditions, where the more soluble iron(II) is formed by reduction. The processes related to these two options for dissolving WWS and the available facilities at the WWTP are discussed in the following sections:

Dissolution of the iron and aluminium in WWS can be achieved by adding a strong acid like sulphuric acid $\left(\mathrm{H}_{2} \mathrm{SO}_{4}\right)$ which follows the main reactions (Eqs. 1-4):

$$
\begin{aligned}
& 2 \mathrm{Fe}(\mathrm{OH})_{3}+3 \mathrm{H}_{2} \mathrm{SO}_{4} \rightarrow 2 \mathrm{Fe}^{3+}+3 \mathrm{SO}_{4}^{2-}+6 \mathrm{H}_{2} \mathrm{O} \\
& 2 \mathrm{FeOOH}+3 \mathrm{H}_{2} \mathrm{SO}_{4} \rightarrow 2 \mathrm{Fe}^{3+}+3 \mathrm{SO}_{4}^{2-} \\
& \mathrm{Fe}_{2} \mathrm{O}_{3}+3 \mathrm{H}_{2} \mathrm{SO}_{4} \rightarrow 2 \mathrm{Fe}^{3+}+3 \mathrm{SO}_{4}^{2-}+3 \mathrm{H}_{2} \mathrm{O} \\
& 2 \mathrm{Al}(\mathrm{OH})_{3}+3 \mathrm{H}_{2} \mathrm{SO}_{4} \rightarrow 2 \mathrm{Al}^{3+}+3 \mathrm{SO}_{4}^{2-}+6 \mathrm{H}_{2} \mathrm{O}
\end{aligned}
$$

From these reactions, it can be seen that regardless of the speciation of the aluminium or iron oxides-hydroxides $1 \frac{1}{2}$ mole of sulphuric acid is required to dissolve $1 \mathrm{~mol}$ of iron or aluminium. In practice, more acid will be required since WWS consists of other acid consuming minerals like carbonates and silicates. The acid used for this purpose need not be commercial concentrated acid. Therefore, acidic by-products from different industrial processes can be used. For example, quencher water from flue gas washing process at incineration plants (either from sludge incineration at the WWTP or from coal or garbage incineration plants) contains mainly sulphuric acid with some hydrochloric acid $(\mathrm{HCl})$ and has $\mathrm{pH}$ values lower than 1. Another example is commercial acidic iron solution used as coagulant at WWTP. Other possibilities which depend on local conditions are using concentrated strongly acidic industrial wastewaters. If the WWS is available locally, the acidic dissolution can be environmentally and economically favourable compared to applying commercial iron and aluminium salts based alone on transportation costs since, e.g. sulphuric acid has a lower molar weight than the corresponding iron and aluminium salts and thus less material has to be transported.

Biologically mediated dissolution of iron oxides and hydroxides in the presence of organic matter (represented by the stoichiometric formula: $\mathrm{CH}_{2} \mathrm{O}$ ) under reducing conditions (Eq. 5) is a well-known process in the lithosphere (e.g. Stumm and Morgan 1996).

$$
4 \mathrm{FeOOH}+\left\{\mathrm{CH}_{2} \mathrm{O}\right\}+\mathrm{H}_{2} \mathrm{O} \rightarrow 4 \mathrm{Fe}^{2+}+\mathrm{CO}_{2}+8 \mathrm{OH}^{-}
$$

$2\left\{\mathrm{CH}_{2} \mathrm{O}\right\} \rightarrow \mathrm{CH}_{4}+\mathrm{CO}_{2}$

Considering redox conditions, the same process should also occur under methanogenic conditions in the sludge digester at WWTPs resulting in production of soluble iron(II)and alkalinity at the cost of decreased methane
$\left(\mathrm{CH}_{4}\right)$ production. This iron-rich water can be recirculated to the WWTP with the reject water from dewatering of digested sludge and added either to the primary settlers or aeration tanks at the WWTP, which are the typical iron or aluminium dosage points at a WWTP. According to reactions 5 and $6,8 \mathrm{~mol}$ of iron(II) and $16 \mathrm{~mol}$ of alkalinity are produced at the potential loss of $1 \mathrm{~mol}$ methane. However, the resulting dissolved iron concentration depends on the conditions in the digester and it is likely that the high concentrations of carbon dioxide and alkalinity in the digester may cause some of the produced iron(II) to precipitate as siderite $\left(\mathrm{FeCO}_{3}\right)$ (Eq. 7) and reduce the feasibility of using this method as a source of dissolved iron solution in the WWTP:

$\mathrm{Fe}^{2+}+\mathrm{HCO}_{3}^{-} \rightarrow \mathrm{FeCO}_{3}+2 \mathrm{H}^{+}$

Other important reactions which may occur upon addition of iron-rich WWS to the digester are Eqs. 8 and 9 , where dissolved iron(II) in the presence of phosphate and sulphide precipitates as $\mathrm{Fe}_{3}\left(\mathrm{PO}_{4}\right)_{2}$ and $\mathrm{FeS}$.

$3 \mathrm{Fe}^{2+}+2 \mathrm{H}_{2} \mathrm{PO}_{4}^{-} \rightarrow \mathrm{Fe}_{3}(\mathrm{PO} 4)_{2}+4 \mathrm{H}^{+}$

$\mathrm{Fe}^{2+}+\mathrm{HS}^{-} \rightarrow \mathrm{FeS}+\mathrm{H}^{+}$

The phosphate precipitation reaction (Eq. 8) results in reduced internal recirculation of phosphate through reject water, thereby reducing the cost for phosphate removal in the wastewater treatment. The sulphide removal (Eq. 9) reduces the toxicity in the digester solution and hydrogen sulphide concentrations in the biogas. $\mathrm{H}_{2} \mathrm{~S}$ in natural gas is burned to the corrosive $\mathrm{SO}_{3}$ and $\mathrm{H}_{2} \mathrm{SO}_{4}$ in the gas furnace or electricity producing engine which decreases their lifetime.

Furthermore, the produced alkalinity (reaction 5) may result in an increase in the $\mathrm{pH}$ of the digester liquid, which may be beneficial for the methanogenesis in some digesters with $\mathrm{pH}$ below the optimal. Production of alkalinity can additionally favour the conditions for struvite $\left(\mathrm{NH}_{4} \mathrm{MgPO}_{4}\right)$ formation (Eq. 10), which in practice occurs mainly when the effluent from a sludge digester is degassed and the carbon dioxide stripping causes an increase in $\mathrm{pH}$.

$\mathrm{NH}_{4}^{+}+\mathrm{Mg}^{2+}+2 \mathrm{H}_{2} \mathrm{PO}_{4}^{-} \rightarrow \mathrm{NH}_{4} \mathrm{MgPO}_{4}+2 \mathrm{H}^{+}$

Increased struvite formation in the digester is advantageous since its formation decreases the recycling of ammonia and phosphorous back to the wastewater treatment process, however, in practice, many WWTPs experience problems with struvite precipitation in the centrifuges and pipe network resulting in significant maintenance costs (Charles et al. 2006).

Apart from iron(hydr)oxides, the main elements in the WWSs are calcium, silicium (silicates) and inorganic carbon (carbonates). Other relevant elements are aluminium, 
magnesium and manganese. However, the concentration of these elements in the WWS is less than $1 \%$ of iron concentration (Aktor 1990).

This paper investigates the feasibility of two strategies for applying iron-rich WWS at WWTP: Firstly, the acidic dissolution of WWS with sulphuric acid, flue gas washing water and excess acid in the commercial iron salt; secondly, the reductive dissolution of WWS during anaerobic sludge digestion.

Both the strategies can be separately employed to solve the disposal problem of WWS and at the same time reducing the consumption of chemicals at a WWTP.

\section{Materials and methods}

Iron-rich WWSs were collected from 3 different WWs (Thorsbro, Søndersø and Slangerup) in Denmark to investigate the variability of WWSs. At these WWs groundwater is used as raw water source for water supply employing only simple treatment processes of aeration and sand filtration. The WWSs were rich in iron due to naturally occurring iron in the groundwater.

Dissolution of ocher sludge in acid and acidic products

Laboratory investigations were carried out to study the acidic dissolution of WWS. The applied acids were concentrated sulphuric acid, commercial iron(III) solution (PIX118) with $\mathrm{pH}<1$ and quencher water. The last two acidic products are easily available at all WWTP, where iron is used for removal of phosphate, and flue gas from sludge incineration is treated. The WWS was stirred thoroughly before the experiment to achieve homogeneity.

\section{Sulphuric acid}

The concentrated sulphuric acid applied in the experiment was a $98.6 \%$ pure laboratory grade from Sigma, Denmark. The experiments were conducted in $100 \mathrm{ml}$ beakers, where $10.0 \mathrm{~g}$ wet WWS [2.4 g dry weight (dw)] from Thorsbro WW was added to the beaker followed by the addition of different doses of concentrated sulphuric acid (in the low $\mathrm{pH}$ range from 1.8 to $29.0 \mathrm{~g}$ ) and $1 \%$ sulphuric acid (in the high $\mathrm{pH}$ range from 1.8 to $180 \mathrm{mg}$ ) and the volume was made up to $50 \mathrm{ml}$ using distilled water. The $\mathrm{pH}$ and total iron concentration (after filtering through $0.45 \mu \mathrm{m}$ filters) was measured after $24 \mathrm{~h}$. To investigate the effect of origin of WWS, experiments were conducted with WWSs from all the 3 WWs. In each experiment, $18 \mathrm{~g}$ of concentrated sulphuric acid was added to obtain $\mathrm{pH}$ below 0.5 . The water contents of the sludge varied and, therefore, the wet weight (ww) and dw of the WWS were Thorsbro $3.1 \mathrm{~g} \mathrm{ww}$
(0.73 g dw); Slangerup $6.1 \mathrm{~g} \mathrm{ww}(0.79 \mathrm{~g} \mathrm{dw})$ and Sønders $\varnothing$ $15.1 \mathrm{~g} \mathrm{ww}(1.22 \mathrm{~g} \mathrm{dw})$.

\section{Quencher water}

The quencher water used in the experiment was collected from Lynetten WWTP (Copenhagen, Denmark). The acidity of quencher water at Lynetten WWTP varies considerably from day to day, and the portion collected had a $\mathrm{pH}$ value of 0.6 which is typical. Experiments were conducted by adding different volumes of quencher water (70-234 ml) to $25.3 \mathrm{~g}$ ww WWS (3.75 g dw) from Slangerup WW. The final volume, $\mathrm{pH}$ and total iron concentration (after filtering through $0.45 \mu \mathrm{m}$ filters) were measured after $24 \mathrm{~h}$.

\section{Commercial iron}

The commercial iron solution, named PIX118, from Kemira A/S with $\mathrm{pH}<1$ is among the most common chemical used in Denmark for removal of phosphate at WWTPs. According to the product specifications the product has a $10-15 \mathrm{~g} / \mathrm{kg}$ excess content of sulphuric acid (Kemira A/S, Denmark). Experiments were conducted by adding different volumes of PIX $118(10-80 \mathrm{ml})$ to $25.1 \mathrm{~g}$ wet WWS (3.75 $\mathrm{g} \mathrm{dw}$ ) from Slangerup WW. The final volume, $\mathrm{pH}$ and total iron concentration (after filtering through $0.45 \mu \mathrm{m}$ filters) were measured after $24 \mathrm{~h}$.

\section{Reduction of WWS under anaerobic conditions}

Activated sludge (55\% biological sludge $+45 \%$ primary sludge) and inoculums (from the mesophilic digesters) were harvested from Avedøre WWTP. The anaerobic dissolution of the sludge digester was simulated in $340 \mathrm{ml}$ serum bottles, capped with gastight rubber stopper and sealed with aluminium crimps. All the experiments were performed at an active working volume of $200 \mathrm{ml}$ consisting of predefined doses of WWS, $0.8 \mathrm{~g}$-VS activated sludge, $100 \mathrm{ml}$ inoculum, added in the mentioned order, and the volume was made up to $200 \mathrm{ml}$ by adding tap water. Anaerobic conditions were established by flushing the serum bottles with pure nitrogen gas directly in the liquid phase for $5 \mathrm{~min}$ and the experiments were carried out at $35{ }^{\circ} \mathrm{C}$. To verify the inoculums, biological activity synthetic Avicel PH-100 (Fluka nr. 11363, Sigma-Aldrich) of known methane yield was used as control. Experiments were carried out in duplicate and continued until the gas production was stabilized, i.e. approximately 20 days. The effect of WWS dosage (0-12.5 g dw-WWS/g-VS) was investigated using WWS from Sønders $\varnothing \mathrm{WW}$ and the effect of WWS type was investigated using WWS from Thorsbro WW, Slangerup WW and Sønders $\emptyset \mathrm{WW}$ at a 
constant WWS dose $0.63 \mathrm{~g}$ dw WWS/g-VS. The biogas production was monitored continuously and $\mathrm{pH}$, dissolved iron(II), dissolved total iron, phosphate, and sulphide were measured at the end of the experiments. After the analysis of these parameters, the experiments were continued by adjusting $\mathrm{pH}$ to 4.5 using acetic acid in one of the duplicate to dissolve the precipitated siderite (Poulton and Canfield 2005). Dissolved iron(II) was measured $2 \mathrm{~h}$ after the addition of acetic acid. In the second duplicate, carbon dioxide was degassed using aeration, where air was introduced until the $\mathrm{pH}$ reached to a stable condition and $\mathrm{pH}$, iron(II) and phosphate were measured at the end of the experiments.

\section{Analysis}

Iron(II) was measured using the ferrozin method adopted from Stookey (1970). Ferrozin (3-(2-pyridyl)-5,6-bis-(4phenylsulfonsyre)-1,2,4-triazin) reacts with $\mathrm{Fe}(\mathrm{II})$ to form a stable complex species with maximum absorbance at $562 \mathrm{~nm}$. Total iron was measured using flame atomic adsorption spectrophotometry (FAAS). Phosphate and sulphide were measured using the MERCKs phosphate Cell Test (measuring range $0.01-5 \mathrm{mg} / \mathrm{l} \quad \mathrm{PO}_{4}-\mathrm{P}$ ) and Sulphide Cell Test (measuring range $0.02-1.5 \mathrm{mg} / 1 \mathrm{~S}^{2-}$ ), respectively. Biogas was measured by direct injection of $0.2 \mathrm{ml}$ (Luar lock syringe) of headspace gas to a GC-14 Shimadzu gas chromatograph equipped with a flame ionization detector. The elution and compound separation was carried out by the stationary phase, Molsive 60/80 column $1.8 \mathrm{~m} \times 3 \mathrm{~mm}$ OD and nitrogen as carrier gas, flow $2 \mathrm{~kg} /$ $\mathrm{cm}^{2}$, flame gas was $30 \mathrm{ml} / \mathrm{min} \mathrm{H}_{2}$ and oxygen $30 \mathrm{ml} / \mathrm{min}$ as atmospheric air. The gas chromatograph was calibrated before each analysis by injecting fresh calibration standards of methane in appropriate concentrations.

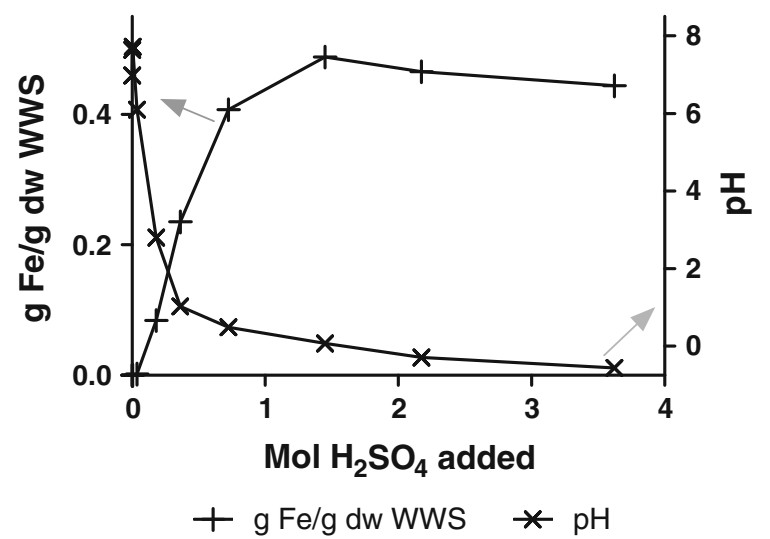

\section{Results and discussion}

Efficiency of acidic dissolutions

\section{Sulphuric acid}

Figure 1 (left) shows the resulting iron concentration and $\mathrm{pH}$ due to acidic dissolution of WWS from Thorsbro WW at various amounts of concentrated sulphuric acid and Fig. 1 (right) shows the effect of WWS origin (Thorsbro WW, Sønders $\varnothing$ WW or Slangerup WW) at constant dosage of concentrated sulphuric acid of $0.15 \mathrm{~mol} / \mathrm{l}(18 \mathrm{~g})$ acid (Fig. 1, right) on dissolved iron concentration. As expected, the dissolution of WWS increased with an increase in the amount of sulphuric acid and reached a maximum at a sulphuric acid concentration of $1.45 \mathrm{~mol} / \mathrm{l}$ with a resulting $\mathrm{pH}$ of 0.49 and dissolved iron concentration of $0.5 \mathrm{~g}-\mathrm{Fe} /$ g-dw-WWS added. Parsons and Daniels (1999) also reported that the optimal $\mathrm{pH}$ for dissolution $99 \%$ iron from WWS was 0.5 . The dissolution experiments on origin of WWS (Fig. 1, left) show that the iron content of the WWSs was in the range of $0.37-0.6 \mathrm{~g}-\mathrm{Fe} / \mathrm{g}-\mathrm{dw}-\mathrm{WWS}$ and that the amount of iron dissolved varied with the WWS origin, even though the final $\mathrm{pH}$ for the 3 studied WWSs was below 0.5 and the WWS seemed to be dissolved completely. Aktor (1990) reported $0.4 \mathrm{~g}-\mathrm{Fe} / \mathrm{g}-\mathrm{dw}-\mathrm{WWS}$ to be typical iron content of WWS from Denmark. Duplicate experiments with WWS from Thorsbro and Slangerup show that variation in the iron content was up to $15 \%$.

\section{Quencher water}

Figure 2 (left) shows the dissolution of WWS with quencher water. As expected, an increase in the volume of quencher water resulted in an increase in soluble iron and

Fig. 1 Dissolution of WWS with varying $\mathrm{H}_{2} \mathrm{SO}_{4}$ dosages and constant WWS dosage of $2.4 \mathrm{~g}$ dw from Thorsbro WW (left) and with WWS from different WWs at optimal $\mathrm{H}_{2} \mathrm{SO}_{4}$ dosage resulting in pH below 0.5 (right). The arrows indicate which axis the curves are related to 

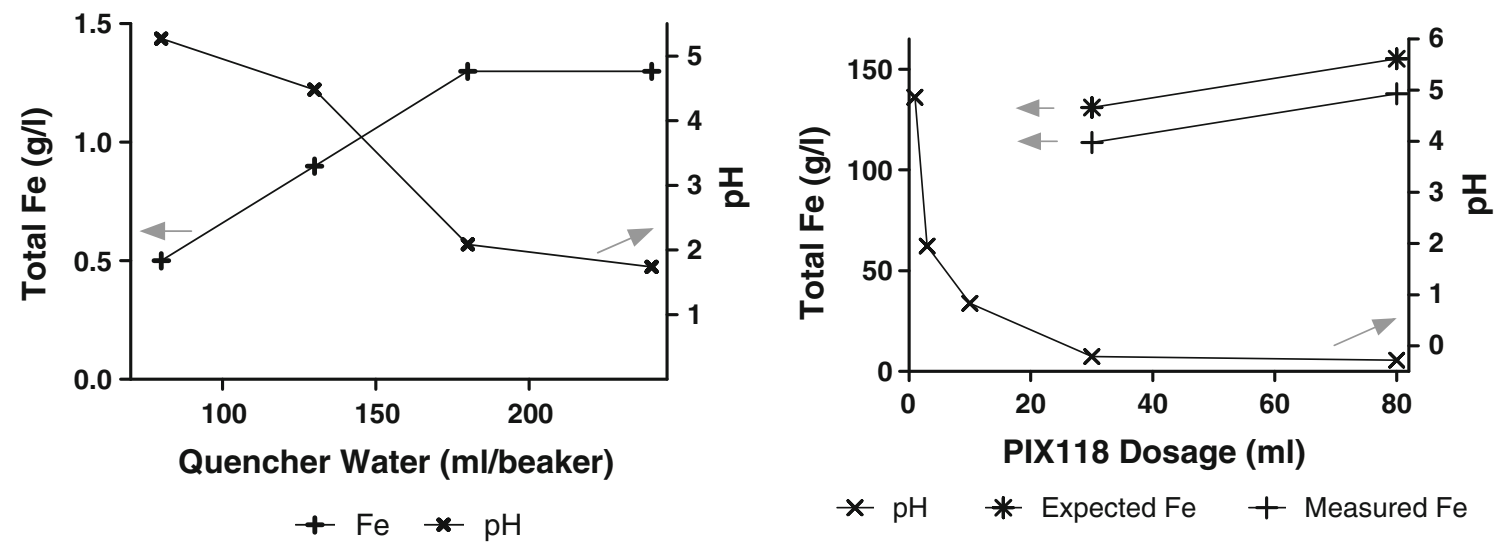

Fig. 2 Dissolution of 3.75 g-dw WWS with varying volumes of quencher water (left) and PIX 118 (right). The arrows indicate which axis the curves are related to

decrease in $\mathrm{pH}$. The highest quencher water dosage of $240 \mathrm{ml}$ decreased the $\mathrm{pH}$ to 1.7 and the resulting dissolved iron concentration was $0.18 \mathrm{~g}-\mathrm{Fe} / \mathrm{g}-\mathrm{dw}-\mathrm{WWS}$. The maximum dissolution with sulphuric acid for this batch of WWS was $0.55 \mathrm{~g}-\mathrm{Fe} / \mathrm{g}$-dw-WWS. If $\mathrm{pH}$ (Fig. 1, left) is used as an indicator for dissolution the expected amount of iron dissolved at pH 1.7 is approximately $0.17 \mathrm{~g}-\mathrm{Fe} / \mathrm{g}$-dw WWS, which agrees well with the measured data.

\section{Commercial iron}

Acidic dissolution with PIX118 (Fig. 2, left) also showed that the $\mathrm{pH}$ decreased with an increase in PIX118 addition. The expected iron concentrations based on the results on dissolution with sulphuric acid and measured iron concentrations are shown in Fig. 2 (left). The results show that the measured iron concentrations were 10-15\% lower than the calculated concentrations based on the $\mathrm{pH}$ dissolution curve (Fig. 1, left), which are within the expected uncertainties involved in the analytical procedures.

Anaerobic dissolution of WWS in anaerobic digester

Figure 3 shows the effect of WWS on biogas production (Fig. 3a), pH (Fig. 3b), iron(II) concentration (Fig. 3c) and phosphate and sulphide concentrations (Fig. 3d).

\section{Methane}

The results on biogas production show that the addition of WWS dosage up to $0.3 \mathrm{~g}$-dw-WWS/g-VS did not have any negative effect on the biogas production, whereas the biogas production decreased by $20 \%$ in the WWS dosage range of $0.63-1.25 \mathrm{~g}-\mathrm{dw}-\mathrm{WWS} / \mathrm{g}-\mathrm{VS}$ and by $40-50 \%$ at WWS dosage of $6.25-12.5 \mathrm{~g}-\mathrm{dw}-\mathrm{WWS} / \mathrm{g}-\mathrm{VS}$. This decrease in biogas production is expected according to Eq. 5 .

\section{Effect of WWS on pH in digester and reject water}

The $\mathrm{pH}$ dropped slightly at the lowest WWS dosage of $0.16 \mathrm{~g}-\mathrm{dw}-\mathrm{WWS} / \mathrm{g}-\mathrm{VS}$ and thereafter increased with increased WWS dosage, but only up to WWS dosage of $6.35 \mathrm{~g}-\mathrm{dw}-\mathrm{WWS} / \mathrm{g}$-VS. The increase in $\mathrm{pH}$ with increased addition of WWS is expected according to Eq. 5. However, further increase in the WWS to $12.5 \mathrm{~g}$-dw-WWS/g-VS resulted in lower $\mathrm{pH}$ compared to WWS dosage of $6.35 \mathrm{~g}-\mathrm{dw}-\mathrm{WWS} / \mathrm{g}-\mathrm{VS}$. This could be due to the toxic effect of WWS on the microbial community.

\section{Soluble iron}

As expected, the dissolved iron concentration increased with an increase in the WWS dosage (Fig. 3c) up to $0.31 \mathrm{~g}-\mathrm{dw}-\mathrm{WWS} / \mathrm{g}$-VS and thereafter decreased with an increase in the WWS dosage. Furthermore, the resulting iron concentrations were 1,000 times lower than the expected concentrations based on Eq. 5. The observed trend in the dissolved iron concentrations can be explained by the combination of Eqs. 5 and 7, where an increased WWS dosage increases the $\mathrm{pH}$ and carbon dioxide pressure resulting in conditions favourable for siderite precipitation (e.g. Stumm and Morgan 1996). The obtained results with acetic acid dissolution prove this interpretation. The results further show that even the control experiments with no addition of WWS resulted in high dissolved iron concentrations at $\mathrm{pH}$ 4.5. The results from the experiments with aeration of the digested sludge show a further decrease in the soluble iron concentration.

The lower reduction in the produced methane gas, lower increase in $\mathrm{pH}$ and lower soluble iron(II) with acetic acid at $12.5 \mathrm{~g}$-dw-WWS/g-VS than expected indicate that WWS dosage as high as this might have a toxic effect on methane production and iron reduction. 

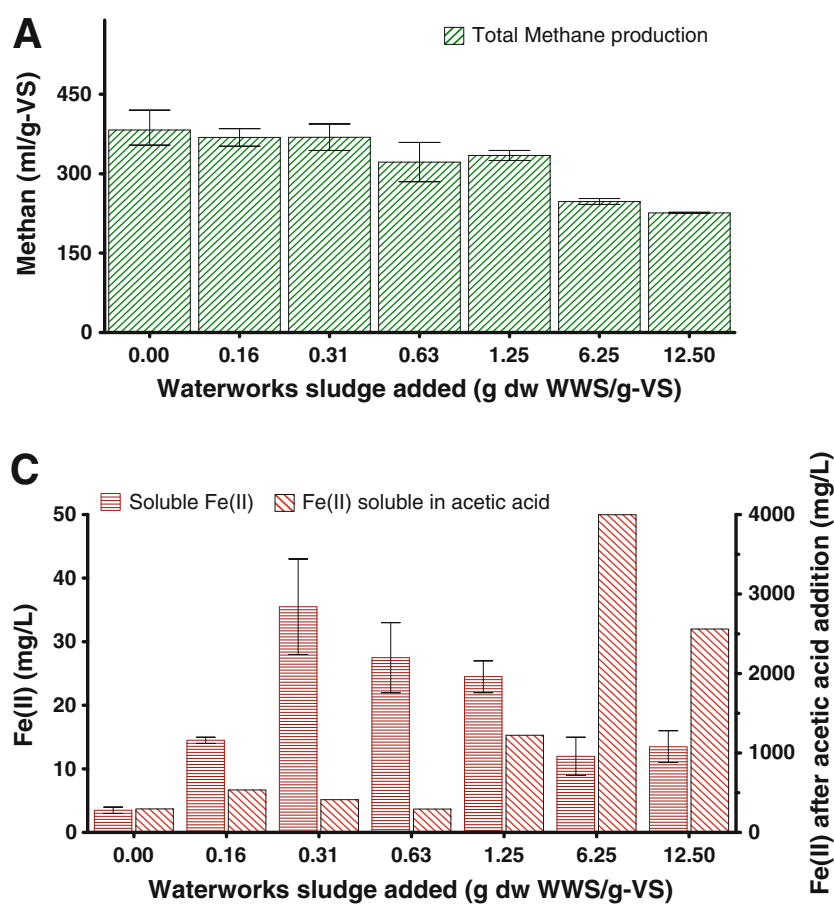

Fig. 3 Effect of WWS dosing in anaerobic digesters on: a methane production, $\mathbf{b} \mathrm{pH}$ after methane production has ceased and following aeration of this to remove $\mathrm{CO}_{2}$ from the digester liquid. c Soluble iron(II) concentrations with and without addition of acetic acid to

The results indicate that even though anaerobic dissolution of WWS in the digesters is possible, the applicability of this method for continuous supply of iron(II) to remove phosphate in the inlet to a WWTP is limited due to high carbon dioxide and $\mathrm{pH}$ that causes siderite precipitation (e.g. Stumm and Morgan 1996).

\section{Effect of WWS dosage on dissolved sulphide and phosphate}

The anaerobic condition in the digester is favourable for the release of biologically removed phosphate and generation of hydrogen sulphide resulting in higher phosphate and sulphide concentrations. At Avedøre WWTP, the phosphate load from the reject water accounts for approximately $10-20 \%$ of the total phosphate load on the wastewater treatment process. The results from the experiments shows that the addition of WWS reduced the phosphate concentration from $66 \mathrm{mg}-\mathrm{P} / \mathrm{l}$ without addition of WWS to only $15 \mathrm{mg}-\mathrm{P} / \mathrm{l}$ with addition of $0.16 \mathrm{~g}-\mathrm{dw}-\mathrm{WWS} / \mathrm{g}-\mathrm{VS}$ and $3.2 \mathrm{mg} / \mathrm{l}$ at $0.31 \mathrm{~g}-\mathrm{dw}-\mathrm{WWS} / \mathrm{g}-\mathrm{VS}$.

Similarly, for sulphide concentrations, the results indicate that the additionally produced dissolved iron(II) from the WWS addition is effective in removing sulphide, thereby reducing the sulphide toxicity and decreasing the corrosion of the gas engines.

The results from the experiments with aeration show that aeration decreased the phosphate concentration in all
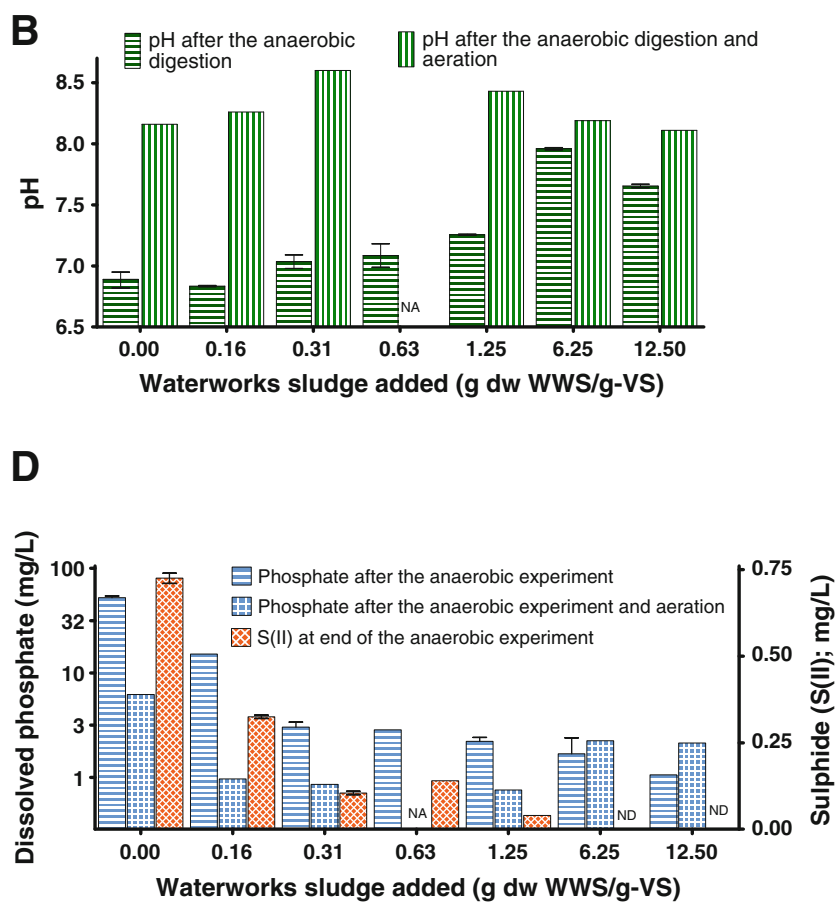

dissolve $\mathrm{FeCO}_{3}$. d Dissolved sulphides and phosphate after methane production has ceased. T-bars indicate the range of duplicate analysis for $\mathbf{a}$ and $\mathbf{c}$ and for triplicate analysis for $\mathbf{b}$ and $\mathbf{d}$

the experiments. Even in the absence of WWS, the phosphate concentration decreased from 50.5 to $6.2 \mathrm{mg} / \mathrm{l}$, whereas in the presence of WWS the phosphate concentration decreased to below $1 \mathrm{mg} / \mathrm{l}$ already at the lowest WWS dosage of $0.16 \mathrm{~g}-\mathrm{dw}$ WWS/g-VS. This is explained by the produced alkalinity from WWS dissolution which causes a further increase in $\mathrm{pH}$ during the degassing of the carbon dioxide compared to controls.

Scenarios for metals of environmental concern from WWS pollution of water and sludge

Since the WWS is not only rich in iron, but also contains trace metals of environmental concern as shown in Table 1, two worst case scenario calculations were carried out to evaluate the potential effect of reuse of WWS on concentrations of metals of environmental concern in water (water scenario) and sludge (sludge scenario). Avedøre WWTP was considered as the case study and it was assumed that WWS would replace the commercial iron (PIX 118) addition entirely. The worst case assumption made for the water scenario was that all the metals of environmental concern will end up in the effluent water from Avedøre WWTP. The worst case assumption made for the sludge scenario was that all the metals of environmental concern will end up in the dewatered sludge from Avedøre WWTP. The calculated amounts were compared to the existing 
Table 1 Metal concentrations in the waterworks sludge from Thorsbro WW, Slangerup WW and Sønders $\varnothing$ WW and the digested sewage sludge from Avedøre WWTP as well as inlet wastewater and effluent compared with guideline values

\begin{tabular}{|c|c|c|c|c|c|c|c|c|}
\hline & \multicolumn{3}{|c|}{ Waterworks sludge } & \multicolumn{3}{|c|}{ Avedøre WWTP } & \multicolumn{2}{|c|}{ Quality criteria } \\
\hline & $\begin{array}{l}\text { Thorsbro WW } \\
\text { (mg/kg-dw) }\end{array}$ & $\begin{array}{l}\text { Slangerup WW } \\
(\mathrm{mg} / \mathrm{kg}-\mathrm{dw})\end{array}$ & $\begin{array}{l}\text { Sønders } \emptyset \mathrm{WW} \\
(\mathrm{mg} / \mathrm{kg}-\mathrm{dw})\end{array}$ & $\begin{array}{l}\text { Influent } \\
\text { water }(\mu \mathrm{g} / \mathrm{l})\end{array}$ & $\begin{array}{l}\text { Effluent } \\
\text { water }(\mu \mathrm{g} / \mathrm{l})\end{array}$ & $\begin{array}{l}\text { Dewatered } \\
\text { sludge } \\
(\mathrm{mg} / \mathrm{kg}-\mathrm{dw})\end{array}$ & $\begin{array}{l}\text { Sludge } \\
(\mathrm{mg} / \mathrm{kg}-\mathrm{dw})\end{array}$ & $\begin{array}{l}\text { Water } \\
\text { (marine) } \\
(\mu \mathrm{g} / 1)\end{array}$ \\
\hline Arsenic & 232 & B.D. & B.D. & 2.5 & 1.6 & 4.3 & 1,000 & 0.11 \\
\hline Cadmium & 8.9 & 5.9 & 0.6 & 0.3 & 0.19 & 2.6 & 0.8 & 0.2 \\
\hline Chromium & 0.8 & B.D. & B.D. & 39 & 3.6 & 32 & 100 & 3.4 \\
\hline Copper & 16 & B.D. & 19 & 10 & 6.4 & 370 & 1,000 & 1.0 \\
\hline Nickel & 227 & 9.6 & 15 & 9.7 & 6.5 & 39 & 30 & 0.23 \\
\hline Lead & 8.2 & - & 29 & 9.0 & 1.0 & 44 & 120 & 0.34 \\
\hline Zinc & 550 & 42.2 & 56 & 170 & 58 & 1,100 & 4,000 & 7.8 \\
\hline
\end{tabular}

Values exceeding the guideline values are highlighted in bold

$B D$ below detection limit

Table 2 Worst case scenarios on concentrations of metal of environmental concern in the effluent and dewatered sludge from Avedøre WWTP by application of WWS as replacement of commercial iron

\begin{tabular}{|c|c|c|c|c|c|c|}
\hline & \multicolumn{3}{|l|}{ Water scenario } & \multicolumn{3}{|l|}{ Sludge scenario } \\
\hline & \multicolumn{3}{|c|}{ Increase in concentrations in the effluent } & \multicolumn{3}{|c|}{ Increase in concentrations in the dewatered sludge } \\
\hline & Thorsbro WW (\%) & Slangerup WW $(\%)$ & Sønders $\varnothing \mathrm{WW}(\%)$ & Thorsbro WW (\%) & Slangerup WW (\%) & Sønders $\varnothing \mathrm{WW}(\%)$ \\
\hline Arsenic & 196 & 0 & 0 & 242 & 0 & 0 \\
\hline Cadmium & 64 & 53 & 5 & 10 & 7 & 1 \\
\hline Chromium & 0 & 0 & 0 & 0 & 0 & 0 \\
\hline Copper & 3 & 0 & 4 & 0 & 0 & 0 \\
\hline Nickel & 47 & 2 & 3 & 28 & 1 & 2 \\
\hline Lead & 11 & 0 & 38 & 1 & 0 & 3 \\
\hline Zinc & 13 & 1 & 1 & 2 & 0 & 0 \\
\hline
\end{tabular}

concentrations of metals of environmental concern in the effluent and dewatered sludge from Avedøre WWTP (Tables 1,2). For the sludge scenario, it was evaluated if the Danish guideline values for deposition of sludge on agricultural land (Slambekendtgørelsen 2006) were exceeded. The effluent from Avedøre WWTP is discharged $1 \mathrm{~km}$ off the coast into the Køge Bay and there are at present no guideline values for the metal concentrations in the effluent from the WWTP. Therefore, it was evaluated if the water quality criteria for discharges to the marine waters (Bek1022 2010) were exceeded.

Table 1 shows the metal of environmental concern concentrations in WWS from Thorsbro WW, Slangerup WW and Søndersø WW as well in influent, effluent and dewatered sludge from Avedøre WWTP together with quality criteria for marine water and sludge.

The metal of environmental concern concentrations of the investigated WWSs depended on the origin of the WWS. Thorsbro WW contained the highest concentrations of metals of environmental concern. The concentrations of cadmium and nickel in WWS from Thorsbro WW exceeded the Danish sludge criteria, which was also the case for the dewatered sludge from Avedøre WWTP. In WWS from Slangerup WW, only cadmium was above the limit. Arsenic, copper, nickel, lead and zinc exceeded the guideline value for effluent water from Avedøre WWTP.

Table 2 shows the predicted effect of addition of WWS on the concentration of metals of environmental concern in the effluent (water scenario) and dewatered sludge (sludge scenario) from Avedøre WWTP for the two worst case scenarios.

The results for worst case scenario for water showed $>10 \%$ increase in the effluent concentrations of arsenic, cadmium, nickel, lead and zinc for WWS from Thorsbro WW, cadmium for WWS from Slangerup WW and lead for WWS from Søndersø WW. Comparison of effluent concentrations from Avedøre WWTP without addition of WWS (Table 1) with calculated concentrations from the worst case water scenario (Table 2) showed that except for cadmium the effluent concentrations of all the other metals 
metal of environmental concern already exceeded the water quality criteria before the application of WWS. However, the effluent is discharged $1 \mathrm{~km}$ away from the coast in the Køge bay with an estimated initial dilution of 6 . If this dilution is applied the water quality criteria will only be exceeded for Arsenic, Copper and Nickel both with and without the addition of WWS.

The results for worst case scenario for sludge showed $>10 \%$ increase in the dewatered sludge concentrations of arsenic, cadmium and nickel for WWS from Thorsbro WW. However, the increased arsenic concentration in the dewatered sludge upon addition of WWS was below the Danish sludge criteria. Comparison of dewatered sludge concentrations from Avedøre WWTP without addition of WWS (Table 1) with calculated concentrations from the worst case sludge scenario (Table 2) showed that the effluent concentrations of cadmium and nickel in the dewatered sludge from Avedøre WWTP already exceeded the guideline values before the application of WWS.

Perspectives for use of the suggested processes

The yearly consumption cost of commercial iron solution for phosphate removal is approximately 1.0 million DKK (Danish kr.) at Avedøre WWTP. The yearly cost for deposition of the WWSs from the three investigated WWs is 1.2 million DKK and the iron content of the WWSs produced from the three investigated WWs is equal to $50 \%$ of the commercial iron used at Avedøre WWTP. By assuming that the WWS replaces $50 \%$ of the commercial iron purchased the expected yearly savings are 0.5 million DKK because of reduced costs for iron purchase at the plant and 1.2 million DKK for depositing the WWSs. It is estimated that the cost of transporting the iron sludge and dosing it in the WWTP is equal to the handling cost associated with the alternative handling and transport to the controlled landfill. This expected annual total savings of 1.7 million DKK are equivalent to about $13 \%$ of the total operating cost of Avedøre WWTP.

These laboratory investigations resulted in full scale investigation of acidic dissolution of WWTP at Lynetten WWTP and anaeorobic dissolution at Holbæk WWTP.

\section{Conclusion}

The laboratory experiments show that acidic dissolution of WWS can be achieved with concentrated sulphuric acid, quencher water and PIX 118.

The laboratory experiments further show that usage of anaerobic dissolution of WWS as a source of continuous supply of soluble iron is limited due to the equilibrium conditions in the digester causing quenching of soluble iron in the form of iron carbonates and other iron products. Furthermore, the soluble iron concentrations are reduced due to the degassing process occurring during the sludge stabilization process. However, this method has advantages in the form of reducing internal phosphate loads and the sulphide concentration in the biogas and thereby reducing the operational costs.

Both processes can be automated and hence does not need any skilled labour for operation and are more cost effective and environmental beneficial ways of using WWS compared to deposition at controlled landfills.

Based on the results presented here full scale application of acidic dissolution is currently being evaluated at Lynetten WWTP (Copenhagen, Denmark) and anaeorobic dissolution of WWS is about to be tested in full scale at Holbæk WWTP (Central Seeland, Denmark).

Acknowledgments This investigation was partially financed by Udviklingssamarbejdet, Vandcenter Syd og Aarhus Vand. The authors like to thank Gert Petersen, Jes La Cour Jansen, Thomas Guildal, Niels Bent Johansen, Charlotte Frambøl, Jesper Elkjær and Mogens Henze for fruitful discussions on WWTP processes and practices.

\section{References}

Aktor H (1990) Okkerslam. Karakterisering af Vandværksokkerslam og vurdering af betydningen af naturgivne forhold og fysiskekemiske processer. (Ocher. Characterization of Waterworks Sludge and assessment of the importance of natural conditions and physical-chemical processes). PhD thesis. Technical University of Denmark. (http://www.env.dtu.dk/English/Publications/ PhD-Thesis-1973-2010.aspx)

Babatunde AO, Zhao YQ (2007) Constructive approaches toward water treatment works sludge management: an International review of beneficial reuses. Crit Rev Environ Sci Technol 37: $129-164$

Babatunde AO, Zhao YQ (2010) Equilibrium and kinetic analysis of phosphorus adsorption from aqueous solution using waste alum sludge. J Hazard Mater 184(1-3):746-752. doi:10.1016/j.jhazmat. 2010.08.102

Bækgaard A (1997) Introduction to water supply in Denmark. Water Supply 65(6):270-272

Basibuyuk M, Kalat DG (2004) The use of waterworks sludge for the treatment of vegetable oil refinery industry wastewater. Environ Technol 25:373-380

Bek1022 (2010) Environmental quality standards for water and requirements for the discharge of pollutants into streams, lakes or the sea Marin waters (Statuary order 1022 of the Danish State). https://www.retsinformation.dk/Forms/R0710.aspx?id= 132956. Accessed 18 June 2012

Charles W, Cord-Ruwisch R, Ho G, Costa M, Spencer P (2006) Solutions to a combined problem of excessive hydrogen sulphide in biogas and struvite scaling. Water Sci Technol 53(6):203-211. doi:10.2166/wst.2006.198

DANVA (2009) Vejledning i håndtering af okkerslam (Guidelines for handling of Ocher sludge). Danva vejledning nr. 84. ISBN: 978-87-92651-03-7. (http://www.danva.dk/Admin/Public/DWS Download.aspx ?File $=\%$ 2fFiles $\% 2 \mathrm{fFiler} \% 2 \mathrm{fUd}$ dgivelser $\% 2 \mathrm{f} 2011$. 05.06-Vejledning-okkervejledning-CF.pdf) 
Dharmappa HB, Hasia A, Hagare P (1997) Water treatment plant residuals management. Water Sci Technol 35(8):45-56

Dixit S, Hering JG (2003) Comparison of Arsenic(V) and As(III) sorption onto iron oxide minerals: implications of arsenic mobility. Environ Sci Technol 37:4182-4189

Dobbie KE, Heal KV, Aumônier J, Smith KA, Johnston A, Younger PL (2009) Evaluation of iron ochre from mine drainage treatment for removal of phosphorus from wastewater. Chemosphere 75(6):795-800

Heal K, Younger PL, Smith K, Glendinning S, Quinn P, Dobbie K (2003) Novel use of ochre from mine water treatment plants to reduce point and diffuse phosphorus pollution. Land Contam Reclam 11(2):145-152. doi:10.2462/09670513.808

Heal KV, Dobbie KE, Bozika E, McHaffie H, Simpson AE, Smith KA (2005) Enhancing phosphorus removal in constructed wetlands with ochre from mine drainage treatment. Water Sci Technol 51(9):275-282

Ippolito JA, Barbarick KA, Heil DM, Chandler JP, Redente EF (2003) Phosphorous retention mechanisms of a water treatment residual. J. Environ Qual 32:1857-1864

Ippolito JA, Barbarick KA, Elliott HA (2011) Drinking water treatment residuals: a review of recent uses. J Environ Qual 40(1):1-12

Ishikawa S, Ueda N, Okumura Y, Iida Y, Baba K (2007) Recovery of coagulant from water supply plant sludge and its effect on clarification. J Mater Cycles Waste Manag 9:167-172

Leader JW, Dunne EJ, Reddy KR (2008) Phosphorous sorbing materials: sorption dynamics and physicochemical characteristics. J Environ Qual 37:174-181

Liu Y, Naidu R, Ming H (2011) Red mud as an amendment for pollutants in solid and liquid phases. Geoderma 163:1-12

Lu SG, Bai SQ, Shan HD (2007) Mechanisms of phosphate removal from aqueous solution by blast furnace slag and steel furnace slag. J Zehiang Univ Sci A. 9(1):125-132

Makris KC, Harris WG, O'Connor GA, Obreza TA (2004) Phosphorous immobilization in micropores of drinking-water treatment residuals: implications of long-term stability. Environ Sci and Technol. 38:6590-6596

Parsons SA, Daniels SJ (1999) The use of recovered coagulants in wastewater treatment. Environ Technol 20:979-985

Poulton SW, Canfield DE (2005) Development of sequential extraction procedure for iron: implications for iron partitioning in continentally derived particulates. Chem Geol 214:209-221
Sharma AK, Tjell JC, Mosbaek H (2003) Removal of arsenic using naturally occurring iron. Journal De Physique IV:JP 107(II): $1223-1226$

Sharma AK, Guildal T, Thomsen HR, Jacobsen BN (2011) Energy savings by reduced mixing in aeration tanks: results from a full scale investigation and long term implementation at Avedoere wastewater treatment plant. Water Sci Technol 64(5):1089-1095

Sibrell PL, Montgomery GA, Ritenour KL, Tucker TK (2009) Removal of phosphorus from agricultural wastewaters using adsorption media prepared from acid mine drainage sludge. Water Res 43(8):2240-2250

Slambekendtgørelsen (2006) Bekendtgørelse om anvendelse af affald til jordbrugsformål (Danish statuary order for deposition of garbage on agricultural land). BEK nr 1650 af 13/12/2006 (https://www.retsinformation.dk/Forms/R0710.aspx?id=13056)

Smith S, Takács I, Murthy S, Daigger GT, Szabó A (2008) Phosphate complexation model and its implications for chemical phosphorus removal. Water Environ Res 80(5):428-438

Stookey LI (1970) Ferrozine-a new spectrophotometric reagent for iron. Anal Chem 42(7):779-781

Stumm W, Morgan JJ (1996) Aquatic chemistry, 3rd edn. Wiley, New York

Wei X, Viadero RC, Bhojappa S (2008) Phosphorus removal by acid mine drainage sludge from secondary effluents of municipal wastewater treatment plants. Water Res 42:3275-3284

Yan J, Kirk DW, Charles QJ, Xinan L (2007) Sorption of aqueous phosphorus onto bituminous and lignitous coal ashes. J Hazard Mater 148:395-401

Yang Y, Zhao YQ, Babatunde AO, Kearney P (2009) Two strategies of phosphorous removal from reject water of municipal wastewater treatment plant using alum sludge. Water Sci Technol 60:3181-3188

Zeng L, Li X, Liu J (2004) Adsorptive removal of phosphate from aqueous solutions using iron oxide tailings. Water Res 38: $1318-1326$

Zhao YQ, Razali M, Babatunde AO, Yang Y, Buren M (2007) Reuse of aluminium-based water treatment sludge to immobilize a wide range of phosphorous contamination: equilibrium study with different isotherm models. Sep Sci Technol 42:2705-2721 